\title{
Directing Function of Curriculum Implementation on Leadership Training Level IV in Human Resources Development Agencyof North Sumatera Province (BPSDM Provsu)
}

\author{
Suriya Jaya \\ Human Resorces Development Agency of North Sumatera Province, Indonesia
}

\begin{abstract}
This research aims is to find directingfunction in Curruculum Implementation of Leadership Training Level IV at BPSDM Provsu. The focus of this research is "The Directing Function InCurriculum Implementation of Leadership Training Level IV at BPSDM Provsu". This research uses qualitative naturalistic methods. Data collection techniques used interview techniques, observation, document studies, data analysis using interactive data model analysis Miles and Huberman ie data reduction, data presentation, conclusion drawing. The data validity checks are based on Lincoln and Guba. The research found: First, directing function in curriculum implementation is done at institutional stage and class stage. Second, the directing function of the institutional stage by the structural officials is delivered in the preparatory meeting of the curriculum implementation by the Head of BPSDM with other structural officials, functional officials, administrative staff of BPSDM, in the opening of the training, on program direction by echelon III officials. Third, the directing function of the classroom stage is carried out by the participants in the face-to-face teaching and learning activities in the classroom (on campus), indirect face-to-face learning: taking of ownership / breakthrough I and breakthrough II, and the Self Mastery and bench marking activities to best practice (off campus).
\end{abstract}

Keywords: directing, curriculum implementation, leadership training level IV

\section{BACKGROUND}

As an accredited training institution, BPSDM Provsu will organize leadership training level IV based on the new pattern curriculum of the State/Public Administration Institution of The Republic of Indonesia (LAN-RI) as a national curriculum design that must be guided by accredited training institutions under the guidance of LAN-RI. In order for this activity to proceed as expected, BPSDM Provsu performs one of the directing functions in all phases of work since planning, division of tasks and roles through organizing, implementing and evaluating the implementation of curriculum in leadership training level IV. Through directing functions at the institutional level providing command, information, clarity, motivation, direction, instruction, so that structural officials, staff, functional officials get a clear picture of the work to be done so that there is no overlap in carrying out their duties and responsibilities. At the class level, the trainer performs directing functions in the form of explanations, guidance, clarity, instructions in the implementation of classroom curriculum in teaching and learning situations on campus and off campus at BPSDM Provsu including at self masteryand benchmark to best practice to achieve curriculum targets. Therefore directing functions have an important position in the implementation of leadership training level IV in BPSDM Provsu because successful jobs require directing or briefing to get a clear job description, avoiding overlapping work, facilitating the effectiveness of activities, avoiding inefficiency.Research question in this research is: "How is the directing function in the implementation of curriculum leadership training level IV in BPSDM Provsu". This question will be explored in social background BPSDM Provsu included background, actors, events, and process parameters.

\section{LITERATURE REVIEW}

\section{UnderstandingTheDirectingFunction}

Directing functions are part of other management functions such as planning, organizing, coordinating, evaluation. Usman (2011: 16), Arikunto (2009: 11), Mamduh (2011: 11), Daft (2008: 6), put the directing function as one among other management functions. In the management work, after determining the roles and dividing the tasks into the work group through organizing, the next activity is to perform a directing function to inform as clearly as possible the tasks to be carried out in terms of quantity, quality, and time limits of work, including motivating committees and trainerto maintain the spirit of work. Usman (2011: 16), places a directive function as one among the curriculum management, in addition to planning, organizing, and controlling. According to him the directing included motivation, leadership, power, decision making, communication, 
coordination of negotiation, conflict management, organizational change, interpersonal skills, trust building, performance appraisal, job satisfaction.In line with that opinion, the directing function here is a briefing on the participants of leadership training level IV by trainer in the curriculum of learning activities, giving motivation, giving direction to influence the training participants to have positive attitude in teaching and learning. Trainer function in terms of motivating the training participants is a trainer effort to generate and strengthen the learning impetus of the training participants in accordance with the learning objectives.

\section{The Purpose of Directing Function}

According to Arikunto (2009: 11), direction is a leadership effort to provide clarity, guidance, and instruction to subordinates, before and after tasks implemented. Based on the definition of the briefing is the job by the leadership given to subordinates such as lower level officials or staff that contains the procedures, direction, to do the work, as an effort to prepare for work and after the work is done. This means that direction is done because of work, there are leaders, and subordinates to achieve certain goals. The direction of leadership is that staff get a clear picture of the work to be performed and motivated to do the work as effectively and as efficiently as possible.

Mamduh (2011: 11) states, the briefing includes activities to give direction, influence others, motivate. The most challenging activity in the management function is directing because it is directly dealing with humans. Based on the Mamduh Opinion, the guidance includes giving instructions, explanations, information, directions about a particular job and even motivating others to do something according to the purpose of the briefing. The guidance is usually done by the leader or manager to subordinates to influence and motivate or encourage subordinates to do something to achieve the goal, although according to Yukl (2009: 6) experts are still arguing that one can be a leader but not necessarily a manager like an informal leader, Otherwise managers may not necessarily be leaders because not all managers have subordinates like financial managers. But what is clear in the context of directing reflects the relationship between the manager and the subordinates in order to achieve a common perception of a job.

Directing function is considered urgent because it involves the effort to mobilize human resources (HR) as the dominant resource factor in an organization. Miller and seller (1985: 276) state that one of the most important elements in the implementation plan is professional development. This opinion ensures that HR is the most dominant aspect in the implementation of the curriculum because it is the executor of the institutional and class-level curriculum, as well as the component of other resource mobilizers.

In the context of leadership training level IV the directing function is directed by the leaders at the institutional level to the structural officials, staff, in the committees involved in leadership training level IV activities, and to the trainer, including direction by the leadership to the training participants, and the briefing from trainer to the participants in implementing learning in order to have a positive attitude in achieving successful in the training. The point of leadership direction of the parties related to the implementation of training aims to achieve the target of successfultraining.

\section{The Legal Basis}

The directing function of the training participants by trainer is part of the main duty of trainer. The task of teaching and learning trainer both within the scope of developing logic, ethics, and aesthetics, can not be separated from the direction. To realize the personality of the participants of the training which is balanced intellectual development, attitudes or ethics, with the skills are all done through direction, so that the main tasks of the trainer are carried out in relation to the briefing efforts conducted by the trainer. The main duty of trainer according to Article 4 of Regulation of the Minister of Administrative Reform (PERMENPAN) number 14 in 2009 on trainerfunction position is to educate, teach and train. Based on that, the trainer in directing the teaching and learning activities in the training have two main roles: (1) the task of motivating the training participants, (2) guiding or directing the training participants in order to achieve the learning objectives. In teaching and learning activities trainer not be separated from the effort to motivate the training participants to be able to lead to the achievement of goals through the provision of motivation. Through the motivation is expected the training participants can be encouraged and remain eager to follow and complete the leadership trainer level IV.

\section{The Role of Motivation in the Directing Function}

Trainer function in terms of motivating the training participants is a trainer effort to generate and strengthen the learning impetus of the training participants in accordance with the learning objectives. Motivation by Kreitner and Kinicki (2007), : The term motivation drives the latinword movere, meaning "to move" in the present context, Motivation represent the psychological process that causes the direction, direction, and perception of voluntary action that are goal directed. The term Motivation comes from the Latin word movere, meaning "to move" in this context, motivation is a psychological process that causes passion, direction, and perseverance of voluntary action directed towards a goal. Based on the definition, the motivation by trainer 
to the training participants is an effort to encourage psychological training participants to be passionate, have direction and perseverance in the form of voluntary action to achieve learning objectives. If the training participants have the motivation to learn it will facilitate trainer in directing the teaching-learning process to achieve the goal. On the other hand if the training participants are not motivated then the process of teaching and learning can not run effectively. Motivation can arise instantaneously in teaching and learning when starting to learn training materials, it may be because of the content or teaching materials that are considered attractive because it relates to the tasks faced in the work and support the main tasks and functions, related to the problems faced The participants of the training in social interaction or because of the success of trainer provide motivation for the importance of studying the materials of a particular training in an academic perspective. Motivation can arise from future expectations after studying the materials of a particular training can be a desire to be the best in the final value obtained, for example in closing ceremony want to become the training participants with the highest score among other training participants. Thus there is a close relationship between motivation and direction in which the motivation to support directing functions in the implementation of curriculum leadership training level IV. To motivate the participants in the training in learning In order for the training participants to be motivated in learning according to Kreitner and Kinicki (2007), there are three factors that influence: (1) Relevant, (2) Profitable, (3) Interesting. The relevance factor is the suitability between the training materials with the problems and the tasks and personal life in the training participants.

Based on that opinion, the strategy to generate the motivation of the training participants in learning can be done as follows: First, conditioned learning in the training is related to matters relating to the tasks faced by the training participants. The interest of the training participants will be higher if the training materials obtained in the training have a significant relevance to the daily tasks, so as to have practical value. Second, the training materials should be able to improve the competence of the training participants that can add value to the performance. Learning motivation tends to emerge for the training participants if it is beneficial from the aspect of the improvement of useful competence to support the improvement of performance. Third, building a fun teaching learning situation. The interest of the training participants will arise when the training is able to attract the attention of the participants by conditioning the conducive education atmosphere in the sense of comfortable learning, calm, clean, harmonious, democratic without pressure, and dynamic learning interaction. To be able to realize the conditions of such training, can be done if the learning using varied methods, learning media in accordance with training materials, training materials that are challenging, supported by adequate facilities and learning facilities. Such situations can generate motivation to learn the training participants to involve themselves in the learning process. The other role of trainer in the teaching and learning process is to guide the training participants in the effort to achieve the learning objectives such as the guide for project change writing and implementation of the change project, and to guide the training participants in bencmark to bestpractice. The trainer's task of guiding participants of leadership training level IV according to the classification of the rank level of education and leadership traininginPermenpan No. 14 of 2009 included the follow-up training for civil servants to achieve the requirements of the competence of Echelon IV in structural positions and the competence of youngfunctional positions or equivalent, Leadership Training Level IV, Functional Training at Level of Youth, and Other technical training. Besides the task of guiding, the training participants in the things that have been stated before, the trainer is also guiding in terms of leading the teaching and learning process, guiding the rules of the discussion, In giving feedback on the discussion, guiding how to learn and how to understand the training materials, guiding the tasks related to training materials, how to make conclution, and so forth.

\section{RESEARCH METHODS}

This research uses qualitative naturalistic method. Collect data by interview technique, observation, document study, using transcript of contact summary sheet. Data analysis using interactive models Miles and Huberman. The technique of examining the data guided Lincoln and Guba (1985) is by testing the credibility, transferability, dependability, confirmability. Data sources extracted from context-based social situations are illustrated to the discovery of the behavior of actors including echelon II, III and IV officials, staff, trainer, documents and physical and non-physical internal and external environments related to the directing function in the implementation of the curriculum leadership training level IV at BPSDM Provsu.

\section{RESULT}

According to Terry and Leslie (1982: 83), direction is an activity to integrate the efforts of group members to achieve the goals of the group. All group efforts require direction when they wants to achieve goals. Based on the results of this study, the directing function in the implementation of training curriculum is done through two important stages, namely directing function in the implementation of institutional stage, and directing function in the implementation of the classroom stage. At the institutional stage of directing function performed by the Head of Provincial BPSDM and structural officials of echelon III in charge of leadership 
training level IV, while the directing function in the implementation of curriculum class stage done by trainer in teaching-learning situations on campus and off campus including in locus visitation self Mastery and benchmarks to best practice to achieve curriculum targets.

\section{Directing Function in Institutional Stage of Curriculum implementation}

At the institutional stage, directing function in the implementation of curriculum leaderhip training level IV is aimed at two target components of leadership training level IV such as committee in the meeting, and the participants of training in the opening ceremony of training. Directing function that is addressed to the committee and the participants in the meeting is more technical, intended to provide guidance and motivation, and clarity of tasks related to the training, in the hopefully that the training runs as desired so as to achieve the expected goals. It is said to be more technical because the direction emphasizes the aspect of the implementation. The direction of the training participants in the opening ceremony is more oriented to provide support through the explanation of the process and the training stages they will undergo. It is said to be oriented because the directing function emphasizes the recognition and understanding aspects of the training process in accordance with the stages that will be taken by the training participants from the first phase for 13 (thirteen) days with the agenda of Diagnosis of the need for change of organizational change project, phase II 5 (five) days with Agenda Taking Ownersip (Breakthrough I), Phase III 17 (seventeen) days with agenda Designing Project Change and Team Building, Phase IV 60 (sixty) days with agenda Leadership Laboratory, Phase V 2 (two) days Seminar on Change Project Mentor).

At this stage the directing function in the implementation of the curriculum includes the direction of the Head of BPSDM Provsu and echelon III officials in charge of training Pim IV in order to provide input on the implementation of curriculum to the stakeholders concerned with the training Pim IV through the direction and explanation related to the implementation of training to provide a concrete description of how to work the existing committee organization as well as to provide encouragement and motivation about the importance of the tasks assigned to the implementation of leadership training level IV so that the activities run effectively to achieve the goals as planned. Head of BPSDM Provsu as manager performs the role of motivation, communication conveys information through directing function, as well as delegating tasks of leadership training level IV to committee and trainer. This is an expression of his personal skills that a manager needs. According to Stephen P.Robbins and A. Judge Timothy (2007: 9), a leader's management skills must be visible in communicating, motivating, and delegating tasks to subordinates. Through the leadership communication conveys important information, directs the job tasks that will be done as clearly as possible, emphasizes the priority aspects in the effort to achieve the target work completely, dividing the authority possessed based on trust, consideration of the importance of entrusting work to subordinates in the form of task delegation and authority Work is effective.

In line with the definition of the directive, in the directing function of the leadership training level IV, the guiding leadership is the Head of BPSDM Provsu, the echelon III officials that handle leadership training level IV(PIM IV) to subordinate structural officials, trainer, and administrative staff to prepare for the implementation of leadership training level IV and afterwards activities such as reporting to the LAN-RI on the implementation of leadership training level IV activities.

The essence of the directing function of the institutional curriculum implementation is the effort of the leaders (Head of BPSDM and Head of Training for Leadership Training) to give a clear picture about the leadership training level IV, to give explanation, guidance, motivation or encouragement, influence and build trust of the parties in this case officials Structural, functional, organizational, institutional, organizational, mechanism, attention to urgent work, in order to have a positive attitude to be able to perform the functions according to their capacity, duties and roles before leadership training level IV activities are carried out at BPSDM Provsu. Directing function is a function of curriculum management training of leadership training level IV which is considered important because although in organizing has determined the division of tasks and role of institution stage and class stage, but still need further clarity for leadership training level IV running smoothly as expected.

Directing function is carried out by the leader for the work of leadership training level IV that will be done, the priority of the work will be done based on the urgent category, the procedure, the mechanism or the procedure of doing the job. Directing functions can be done by: (1) orientation to identify places, situations, resources, relationships, (2) giving thought thinking about work both orally and in writing, (3) giving opportunities for the contribution of thought and active role to reach the goal, (4) Involving staff in planning, (5) giving advice to subordinates who have difficulty carrying out the task. With the directing function, subordinates will obtain clarity through the instructions given by leader, reaffirm the urgency as well as prevention and warning against possible delays and deviations of work by subordinates in running the training. 


\section{Directing function in the implementation of curriculum diklatPim IV Stage Class}

Directing function carried out by trainer in the implementation of curriculum training is directing and guiding in learning activities in the change project training materials by team trainer as team work of the same training materials. According to Robbins and Coulter (2007: 454) teamworks are groups where members work intensively to achieve common goals or specific goals by positive synergies, individual and collective responsibilities, and complementary skills. The logical consequence of this opinion is the need for mutually synergic cooperation to cover each other's flaws with the team's expertise to achieve the responsibility individually and collectively. The problem that arises is the different perceptions within the same team in giving the order of drafting the Proposal for Change Project, thus causing confusion for the training participants when receiving the briefing information because of the obscurity of informing the work. According to R.Terry George and W.Rue Leslie (1982: 85), the command should tell what to do, who does it, when, where, how, why. The command should be clear so that it is easy to understand, in accordance with its purpose ... is a briefing tool when starting, stopping or changing activities.

In connection with this opinion, the dualism of information submitted by the trainers due to differences in understanding the substance of the training materials, causing the understanding of the participants of different training so as to raise further doubts which should be followed in writing the Project Changes. It shows the unclear command of the trainers about certain aspects that must be done in the work, whereas the command must be clear the meaning, can be easily understood in accordance with the objectives to be achieved in giving the command because the command is the instrument of direction. An order containing information must be clear, complete, concise ... a briefing tool when starting, stopping or changing activities. The dualism of information conveyed by trainer leads to the understanding of different training participants so as to elicit further doubt which one should guide in writing the Change Project.

The directing function of the classroom stage in training is dominant carried out by trainer in two forms, namely direct face-to-face and indirect direction through electronic media. Direct face-to-face activities by trainersare all training materialsbased on structure curriculum of leadership training level IV LAN-RI, except for Change Project materiasl, directing function done in face-to-face in class ie explanation of Project change, Designing Change Project, Implementation of Change Project, exceptTaking Ownership / Breakthrough I, Taking Ownership / Breakthrough II is conducted indirectly through Information Technology (IT).

Direct face-to-face direction is done through face-to-face instructional training such as face-to-face learning, interactive discussions, group discussions on training materials, guidance and learning motivation, visitation, establishing areas of change, adoption and adaptation of benchmark innovations into best practice, designing change projects, Project change design, seminar of change project implementation, Leadership Laboratory. Directing functions can be grouped into the three things: first, directing the teaching and learning process in the internal class BPSDM in the form of face-to-face learning training courses such as face-to-face learning, interactive discussions, training materials group discussions, guidance and motivation to learn. Second, directing of trainer in visitation of Self Mastery and Benchmark to best Practice at Regency / City location which have innovation advantage. Third, directing of trainer in Taking Ownership / Breakthrough I and Taking Ownership / Breakthrough II in their respective institutions through Information Technology.

Indirect directions by the trainer carried out in the activities of Taking Ownership / Breakthrough I and Taking Ownership / Breakthrough II through Information Technology (IT) Black Barry Message (SMS), SMS, Telephone, email. The direction given by the trainers in the activity is not directly done in the form of feedback to the training participants who are required to report the progress of the activity during their respective institution in the activities of campus.

Trainer of training materials on teaching and learning activities ChangeProject and Benchmark to Best Practice training materiasl perform team role. In the direction, trainer has a single role and done individually in each class in the class according to the task of teaching training materials delivered in the classroom. The direction of the team's role is carried out in a group of trainers on the subject of change project training and the implementation of Benchmark activities to Best Practice, as many as 3 (three) persons in a team together in the sama time and schedule, same training materiasl and in the same class. They together at the same time appear in turn to convey the substance of training materials. Team trainer is a coach for training participants in the change project training materials.

From the role of trainer in direct face-to-face or indirect direction, directing of double role and sole role, it is concluded that trainer is required to have professional capability including giving direction, in the learning process both alone and with team according to the learning needs and teaching of training, which can provide guidance, motivation, help to solve the problems of training participants so that learning is more effective. According Hamalik (2005: 145), trainer has a role as a mentor in order to provide assistance of training participants who have learning difficulties in the form of directing, motivating, helping to achieve problem solutions for training participants. In the briefing tutorial, trainer can provide guidance and direction in case the training participants have difficulty in seeing innovation aspect at Benchmark location to Best Practice 
and difficulty in formulating innovation aspect of leadership training level IV participants in activity area according to main task and function. Whereas the formulation of the innovation is used as the capital to prepare the change project which will be used as a tool of bureaucratic reform which will be done by the training participants in their institution in order to meet the standard of change leader as outlined in the curriculum of leadership training level IV LAN-RI inPerkalan-RI Number 13 of 2013.

Directing by trainer means motivating the training participants to be more eager to achieve learning objectives in the training. This means that a trainer in the process of direction has a role motivator. The role of motivator according to Hamalik (2005: 145), is the role of motivation to motivate training participants, in the classroom or outside the classroom in all teaching and learning activities during the training so that the training participants play an active role in following all the learning activities. All teaching and learning activities that are intended in the training is to follow the active teaching and learning in all stages of learning in leadership training level IV on the activities on campus and off campus is taken care by trainer in single role or double role, face to face directly or indirectly.

Based on the directing function of the institutional stage and the classroom stage, the nature of the directing function is the leadership activity to direct, the training participants and the committee, provide orientation, guidance, influence, guide, motivate, clarify and information, build trust of the parties involved in leadership training level IV for the training run effectively and productively. Effective means in the sense of achieving the expected goals, productive in the sense of acquiring desired results.

\section{CONCLUSION}

1. Directing function in the implementation of curriculum leadership training level at BPSDM Provsuin institutional stage is conducting task orientation activities, explaining, informing the target, giving guidelines, influencing, directing, motivating, in order to achieve the leadership Training level IV is effective and productive. The briefing was conducted in two important situations: a preparatory meeting for the implementation of the curriculum with the structural, functional and administrative staff of BPSDM Provsu at the institutional stage, and in the curriculum implementation situation when the opening ceremony of the training was aimed at the training participants to provide support and gain clarity on the process and the stage of training they will live.

2. At the class stage, the directional function is performed by the trainer directly and indirectly. Direct direction is done through face-to-face learning, guidance / motivation of teaching and learning, visitation, training discussion, formulating change area, adoption and adaptation of innovation at benchmark location to best practice, designing of change project, seminar of change project design, Leadership Laboratory. Indirect Directing by trainer on Taking ownership / Breakthrough I, Taking ownership / Breakthrough II, through the Information Technology: when setting the change area and implementation of the change project.

\section{SUGGESTIONS}

1. BPSDM Provsu need to strengthen the cooperation of synergy between the team of fthe Change Project training materials in delivering the direction through the equation of perception and the mastery of the substance of the training materials in more depth so as to minimize the doubt of the training participants in drawing up the Project changes design in the innovation design, and implementing the implementation of the Change Project in Change Management at the Leadership Laboratory stage.

2. Need cooperation between BPSDM Provsu with LAN-RI held training to improve the competence of mastering the substance of the Change Project materials and workshops to equate the perception of trainers in the training team of the Change Project.

\section{REFERENCEES}

[1] HamalikOemar. 2008. Proses BelajarMengajar.Cetakankedelapan. Jakarta: BumiAksara

[2] L.Daft Richard. 2008. Management. Terjemahan Edward TanujayadanShirlyTiolina. Jakarta: SalembaEmpat.

[3] Mamduhhanafi. 2011. Manajemen. Edisiketiga. Yogyakarta: Sekolah Tinggi IlmuManajemen YKPN.

[4] Miller, JP. \& Seller, W.1985. Curriculum: Perspectiveand Practice, New York: Longman.

[5] Robert Kreitner and Angelo Kinicki. 2007. Organizational Behavior, Seventh Edition, New York: Mc Graw-Hill, International Edition

[6] R.Terry George and W.Rue Leslie. 1982. Principles Of Management, four Edition, Printed in the United States of America.

[7] Stephen P Robbins and A.Judge Timothy. 2007. Management. New Jersey: Pearson Prentice Hall.

[8] Stephen P Robbins and Mary Coulter. 2005. Management. New Jersey: Pearson Prentice Hall.

[9] SuharsimiArikunto. 2013. Dasar-Dasar Evaluasi Pendidikan. Edisi 2. Jakarta: BumiAkasara.

[10] Usman Husaini. 2011. ManajemenTeori, Praktek, danRisetPendidikan, Edisi 3, Jakarta: BumiAksara

[11] PeraturanMenteriPendayagunaanAparatur Negara Nomor 14 Tahun 2009 tentangJabatanFungsionalWidyaiswara

[12] Yukl Gary. 2009. Leadership Organization, Edisi Indonesia kelima. Cetakan III, terjemahan, PT Indeks, PT Macanan Jaya Cemerlang 